\title{
WAYS TO FOCUS ON METHODOLOGY OF CHOOSING ISSUES ACCORDING TO THE STUDENTS 'ABILITIES IN PHYSICS CLASSES
}

\author{
Ikrom Abdukarimovich Rakhmonov
}

Lecturer, Department Of General Physics, Termez State University, Uzbekistan

\section{ABSTRACT}

This article discusses how to develop students' skills in physics lessons and how to choose problems. Preschool educational institutions and schools are responsible for the education of students with modern scientific and technical knowledge and understanding, providing quality education and the first lessons in the harmonious development of young people, the proper development of children's worldview.

KEYWORDS:- Ability, creativity, logic, thinking, development, knowledge, skill, competence.

\section{INTRODUCTION}

In our country, great attention is paid to creating social, psychological, pedagogical and methodological conditions for the development of student abilities. Because the mathematical training of young people is of special importance in restoring the intellectual, creative and spiritual potential of our country, which implies not only the formation of mathematical knowledge, skills and abilities, but also the development of mathematical abilities of students. Problems of developing abilities in students, emotional, volitional aspects of personality, as well as character development are closely related to the problems of developing interest in different types of activities.

Any activity requires a person to have several interrelated abilities, not just one ability. In the psychological literature, the lack or slow development of any particular ability may be offset by other strongly evolving abilities. Such a coverage of abilities creates a wide range of opportunities to choose different professions, occupations.

In today's world of globalization and information, the intensification of information attacks requires students to be able to protect themselves from this information, to consider it critically and creatively, and to distinguish what is important and useful to them through logical thinking. This takes place in the process of logical thinking of gifted students.

The fact that a clear definition of the concept of thinking of gifted students today has not yet been developed requires a dialectical approach to the problem. Thinking is a process of cognitive 
CURRENT RESEARCH JOURNAL OF PEDAGOGICS 2(11): 203-208,

November 2021 DOI: https://doi.org/10.37547/pedagogics-crjp-02-11-37

ISSN 2767-3278

(C)2021 Master Journals

Crossref do: 81 Google

Accepted $25^{\text {th }}$ November, 2021 \& Published $30^{\text {th }}$ November, 2021

activity of the person, characterized by direct and generalized reflection of reality. Thinking combines interdisciplinary research, complex sciences.

It is preferable to start the physics course by solving problems on some topics. This is followed by more complex computational, experimental, and other issues that are selected sequentially, with an increasing number of connections between the magnitudes and concepts that characterize the event. Combinations of more complex, incomplete information in a technical context may be the culmination of a system of questions selected on a particular topic.

It is also possible to develop students 'abilities through physics. In this case, in addition to the didactic requirement for the selection of issues, it is important that in the selection of each issue, the teacher achieves the intended purpose. Each chosen topic should contribute to the development of students' knowledge, deepen their understanding of the relationship between adults, clarify concepts and reveal some new features that are not sufficiently defined and deepened in other forms of learning, teach them to apply the acquired knowledge in practice. Problem-solving methods depend on the simplicity or complexity of the problem, the goal set by the teacher, the level of knowledge of the students, and many other reasons.

Here are some basic requirements for teaching students physics to problem-solving techniques. There are general aspects of problem solving that apply to all sections of the physics course, but there are also specific aspects of problem solving methodology that are relevant to each major topic. We will first focus on the general aspects of problem solving below to shape students 'abilities.

Issue 1. (Grade 6 issues). When choosing a issue for a student, there should be questions that first reveal his or her ability parameters. For example, the following issues.

1. Which of the following events is a light event?

a) the train is moving in the subway; b) cooking on an electric stove; c) the sound of a stream is heard; g) the light bulb is on; d) the rotation of an eagle in the sky is observed; e) a movie is shown on TV; j) The snow is melting on the hill.

Solution. g) the light bulb is on; d) the rotation of an eagle in the sky is observed;

2. The number of lines drawn on the measuring tape is 201. Opposite the first line is the number 0 , the last is $100 \mathrm{~cm}$. What are the divisions on the instrument scale? What is the level of the instrument scale?

Given: $\quad n=201$

$$
\frac{l=100 \mathrm{cM}}{\mathrm{k}=?}
$$

Formula: $\mathrm{k}=\mathrm{l}: \mathrm{n}$

Solution. If it consists of 200 pieces, we can calculate it by putting it in the formula.

The instrument scale was 0.5 .

3. How can the thickness of the spool yarn be measured using a measuring tape?

Solution. We make the spools of yarn densely together so that the measuring tape can measure up to $0.5 \mathrm{~cm}$ or $1 \mathrm{~cm}$, and divide it by the number of yarns formed. This results in a single thread diameter.

4. How to measure the size of mosh or pea grains using a beaker?

Solution. We put a certain $\mathrm{ml}$ of water in the beaker, then we put mosh or peas on the water so that the water level in the beaker changes a certain $\mathrm{ml}$. We find the changed ml volume by the number of peas or mosh.

5. Express $497 \mathrm{dm}$ in meters. 
CURRENT RESEARCH JOURNAL OF PEDAGOGICS 2(11): 203-208,

November 2021 DOI: https://doi.org/10.37547/pedagogics-crjp-02-11-37

ISSN 2767-3278

(C)2021 Master Journals

Crossref dof 81 Google

Accepted 25th November, 2021 \& Published 30 th November, 2021

Given: $\underline{1_{1}=497 \mathrm{dm}}$

$$
\mathrm{l}_{2}=\text { ? }
$$

Formula: $1 \mathrm{dm}=0,1 \mathrm{~m}$.

Solution. In solving the problem, the formula is applied and the following result is obtained. 497 - $1 \mathrm{dm}=497 \bullet 0.1 \mathrm{~m}=49.7 \mathrm{~m}$.

Issue 2. (Issues for 7 th grade). Reader ability can also be developed by selecting action-packed tables. In doing so, students will be able to create action charts and apply formulas.

1. Draw speed and road graphs for a car moving straight at a speed of $60 \mathrm{~km} / \mathrm{h}$.

Given: $\underline{\mathrm{v}=60 \mathrm{~km} / \mathrm{hour}}$

$$
\text { Graphics: } v(t)=\text { ?, } s(t)=\text { ? }
$$

Solution: The speed of a smooth motion does not change with time. And the road. $S(t)=v \bullet t$. So the graphs are as follows:

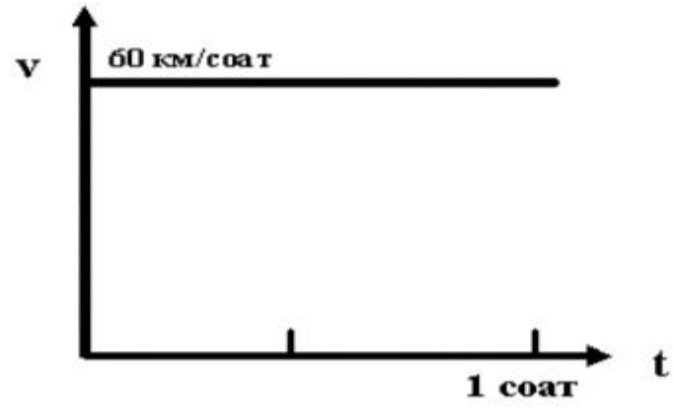

2. In how many minutes can a body moving straight at a speed of $10 \mathrm{~m} / \mathrm{s}$ cover a distance of 6 $\mathrm{km}$ ?

$$
\begin{aligned}
\text { Given: } v & =10 \mathrm{~m} / \mathrm{s} \\
\mathrm{s} & =6 \mathrm{~km}=6000 \mathrm{~m} \\
\mathrm{t} & =?
\end{aligned}
$$

Formula: $v=S: t$ velocity formula

Solution: Find the time from the velocity formula in a plane motion.

Issue 3. (Issues for 7th grade). Now, let's look at issues that develop students 'skills in changing behavior.

1. The body is moving in a flat acceleration with an acceleration of $1 \mathrm{~m} / \mathrm{sec}^{2}$, moving out of place.

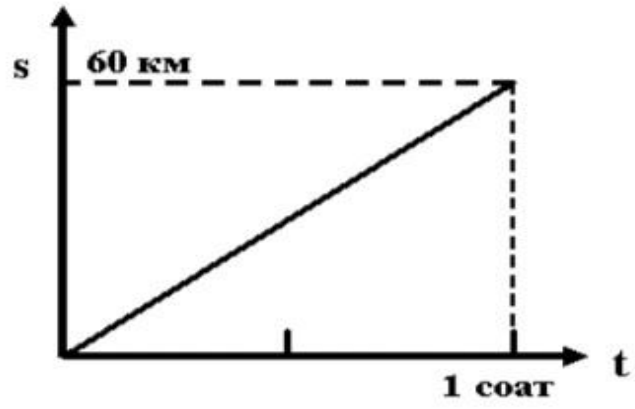

Draw a body motion path graph.

Given: $\mathrm{v}_{0}=0 \mathrm{~m} / \mathrm{s}$

$$
\mathrm{a}=1 \mathrm{~m} / \mathrm{s}^{2}
$$

Graphics: $\mathrm{s}(\mathrm{t})=$ ?

Formula:

$$
s(t)=v_{0} t+\frac{a t^{2}}{2}=\frac{a t^{2}}{2}=1 \frac{M}{c e \kappa^{2}} \frac{t^{2}}{2}
$$

path formula

for smooth accelerating motion.

Solution: From the formula of a path traversed in a smooth accelerating motion 
CURRENT RESEARCH JOURNAL OF PEDAGOGICS 2(11): 203-208,

November 2021 DOI: https://doi.org/10.37547/pedagogics-crjp-02-11-37

ISSN 2767-3278

(C)2021 Master Journals

Crossref do: 81 Google

Accepted 25th November, 2021 \& Published 30 ${ }^{\text {th }}$ November, 2021

graph is as follows (Figure 2).

$s(t)=\mathrm{v}_{0} t+\frac{a t^{2}}{2}=\frac{a t^{2}}{2}=1 \frac{M}{\text { cek }^{2}} \frac{t^{2}}{2}$.

Hence, the

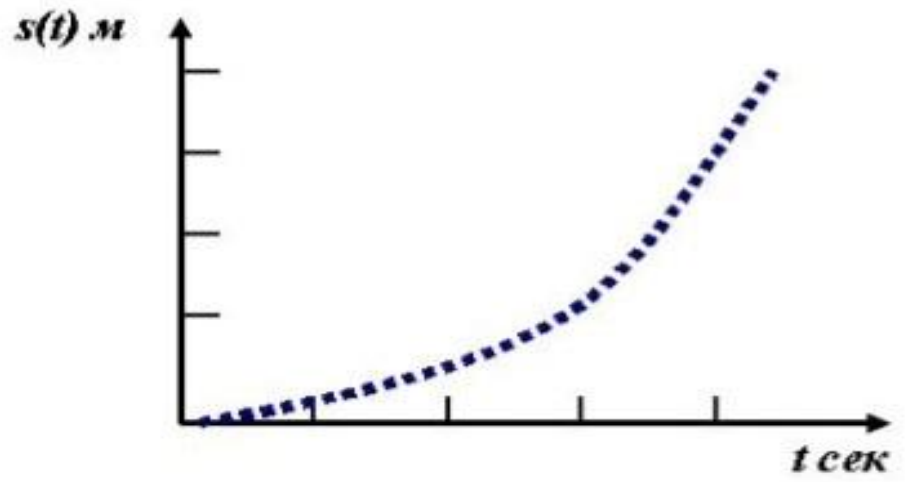

Figure 2

2. A car with an initial speed of $36 \mathrm{~km} / \mathrm{h}$ is moving at a flat acceleration with an acceleration of $0.4 \mathrm{~m} / \mathrm{sec}^{2}$. Draw a traffic graph of the traffic.

Given: $\mathrm{v}_{0}=36 \mathrm{~km} / \mathrm{hour}=36000 \mathrm{~m} / 3600 \mathrm{~s}=$ $\underline{\mathrm{a}=0.4 \mathrm{~m} / \mathrm{s}^{2}}$

Graphics: $s(\mathrm{t})=$ ?

Solution: From the formula of a path traversed in smooth accelerating motion. Hence, the graph is as follows (Figure 3).

$10 \mathrm{~m} / \mathrm{s}$

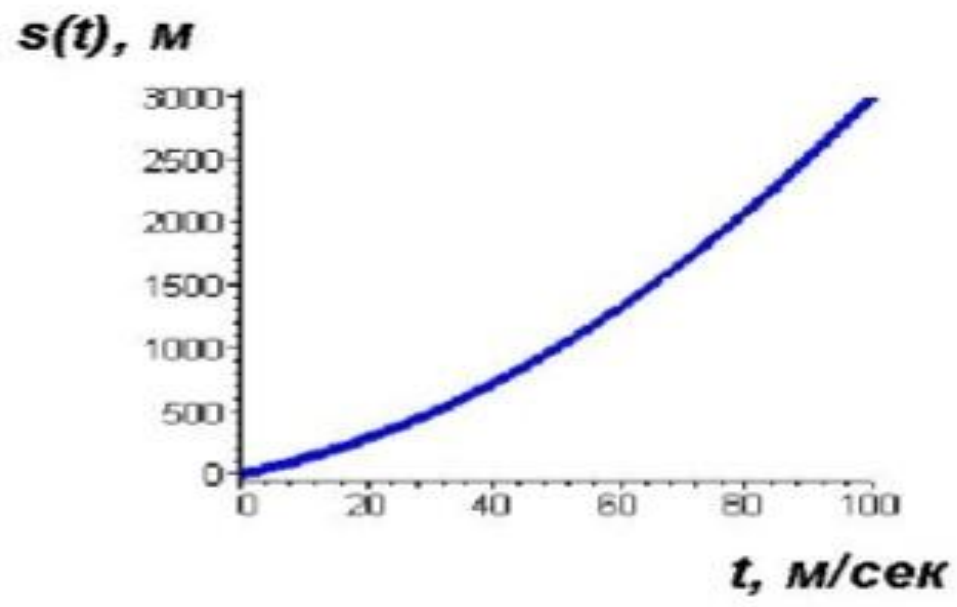

Figure 3

3. A cylinder with an initial velocity of $0.4 \mathrm{~m} / \mathrm{s}$ is rolling upwards along the plane. The cylinder stopped at a distance of $1.8 \mathrm{~m}$. Find the acceleration 
CURRENT RESEARCH JOURNAL OF PEDAGOGICS 2(11): 203-208,

November 2021 DOI: https://doi.org/10.37547/pedagogics-crjp-02-11-37

ISSN 2767-3278

(C)2021 Master Journals

Crossref dof 81 Google

Accepted $25^{\text {th }}$ November, 2021 \& Published $30^{\text {th }}$ November, 2021

and average speed of the cylinder.

Given: $\mathrm{v}_{0}=0.4 \mathrm{~m} / \mathrm{s}$

$$
\begin{gathered}
\mathrm{v}=0 \mathrm{~m} / \mathrm{s} \\
\mathrm{s}=1.8 \mathrm{~m} \\
\mathrm{a}=? \mathrm{~V}_{\mathrm{a}}=?
\end{gathered}
$$

Formula:

$a=\frac{v-v_{0}}{t}=\frac{-0.4}{9} \frac{M}{c e K^{2}}=-0.044 \frac{M}{c e \kappa^{2}}, v_{\text {yp }}=\frac{v+v_{0}}{2}=1 \frac{M}{c e \kappa}$

Formula:

$$
\mathrm{h}=\mathrm{v}_{0} t+\frac{g t^{2}}{2} .
$$

Solution: From the free descent velocity formula (Initial velocity zero),

$$
v=v_{0}+g t=g t=10 \mathrm{~m} / \text { cek }^{2} * 7 \text { cek }=70 \mathrm{~m} / \mathrm{cek}
$$

\section{Descent}

height

Solution: From the average velocity formula in a plane accelerating

motion

$$
v_{\check{y p}}=\frac{v+v_{0}}{2}=\frac{0.4}{2} \frac{M}{c e K}=0.2 \frac{M}{c e K}
$$

$$
\mathrm{h}=\mathrm{v}_{0} t+\frac{g \mathrm{t}^{2}}{2}=\frac{g \mathrm{t}^{2}}{2}=\frac{10 \mathrm{~m} / \mathrm{ceK}^{2} \star(7 \mathrm{ceK})^{2}}{2}=490 / 2 \mathrm{~m}=245 \mathrm{M}
$$

5. What is the velocity of an object thrown If we

find the time from the formula of the path traversed in a plane accelerating motion,

$$
t=\frac{\mathrm{s}}{\mathrm{v}_{\mathrm{yp}}}=\frac{1.8 \mathrm{M}}{0.2 \mathrm{M} / \mathrm{ce} \mathrm{K}}=9 \mathrm{ce} \mathrm{K}
$$

Now let's

find the acceleration

$$
a=\frac{v-v_{0}}{t}=\frac{-0.4}{9} \frac{M}{c e \kappa^{2}}=-0.044 \frac{M}{c^{2} \kappa^{2}} \text {. }
$$

4. An object released from a certain height is falling freely. If the body fell to the ground in 7 seconds, at what height did it fall and at what speed did it fall to the ground?

$$
\begin{aligned}
& \text { Given: } \begin{aligned}
\mathrm{v}_{0} & =0 \mathrm{~m} / \mathrm{s} \\
\mathrm{t} & =7 \mathrm{~s} \\
\mathrm{~g} & =10 \mathrm{~m} / \mathrm{s}^{2} \\
\mathrm{~h} & =? \mathrm{~V}=?
\end{aligned}
\end{aligned}
$$

?, What height does it rise during this time ?, After 4 sec, 6 sec?

$$
\begin{aligned}
& \text { Given: } \begin{aligned}
\mathrm{v}_{0} & =25 \mathrm{~m} / \mathrm{s} \\
\mathrm{g} & =10 \mathrm{~m} / \mathrm{s}^{2} \\
\mathrm{t} & =2,4,6 \mathrm{~s} \\
\mathrm{v} & =?, \mathrm{~h}=?
\end{aligned}
\end{aligned}
$$

Solution: The velocity of an object thrown vertically upwards varies with time as follows. At the top, the speed is zero. It is useful to determine the time elapsed beforehand. Maximum ascent height

$$
h_{m}=\mathrm{v}_{0} t_{\uparrow}-\frac{g t_{\uparrow}^{2}}{2}=(25 * 2.5-5 * 6.25) M=31.25 \mathrm{M} .
$$

It takes as long as it takes to fall: $\mathrm{t}=2.5 \mathrm{~s}$. Total time: $\mathrm{t}=\mathrm{t}+\mathrm{t}=5 \mathrm{~s}$

So, in 2 seconds it is still on the rise, and the 
CURRENT RESEARCH JOURNAL OF PEDAGOGICS 2(11): 203-208,

November 2021 DOI: https://doi.org/10.37547/pedagogics-crjp-02-11-37

ISSN 2767-3278

(C)2021 Master Journals

Crossref do) 81 Google

Accepted 25th November, 2021 \& Published 30th November, 2021

textbook for 7th grade. State Scientific Publishing House "National Encyclopedia of Uzbekistan". -Tashkent, 2017. - 174 p.

speed is

$$
\mathrm{v}=\mathrm{v}_{0}-g t=(25-10 * 2) \mathrm{M} / \text { сек }=5 \mathrm{M} / \mathrm{c}
$$

Elevation in 2 sec: $h=\mathrm{v}_{0} t-\frac{g t^{2}}{2}=(25 * 2-5 * 4) M=30 M$

It will be descending in $4 \mathrm{sec}$ (subtracting the initial velocity from zero and the ascending time from 4 sec), and the velocity is as follows:

$$
\mathrm{v}=\mathrm{v}_{0}-g t=(25-10 * 2) \mathrm{m} / \text { сек }=5 \mathrm{~m} / \text { сек }
$$

6 sec

time - Since the total movement time is more than 5 sec, the object will fall to the ground and the speed will be $0 \mathrm{~m} / \mathrm{sec}$.

It is necessary to strengthen theoretical knowledge in teaching physics. Initially, it is best to ask the student theoretical questions and check his or her level of mastery of the topic. Then it will be easier to achieve the above goals. In determining students 'abilities, however, we selected issues based on which one was preferred.

\section{REFERENCES}

1. Разумовский В.Г. Творчиских способностей учаўихсия в процесс обучения физика. Москва: Просвещение, 1975. - 272 с.

2. Turdiev N.Sh. Physics textbook for 6 th grade. Publishing and Printing House "Uzbekistan". -Tashkent, 2017.- 176 p.

3. Habubullaev P, Boydedaev A. Physics
4. Ibragimov N.Sh. Methods of developing students' mathematical skills by solving special problems // Public education. -2019. - Number 4. -V. 33-40.

5. Berdieva X., Esanniyazova F. Some basic requirements for teaching students the methods of solving problems in physics // Innovative development of Uzbekistan in the eyes of young people. The role of talented youth in the current development of physics. -Tashkent, 2010. -135 p.

6. Raimov G'. F. Psychological components of non-standard situations in solving nonstandard problems in the "Mechanics" section of physics. - Tashkent: // School and life.2020.

7. Raimov G'. F. Features of the student's educational and creative abilities in solving non-standard problems of the "Mechanics" department of physics. -Tashkent: // School and life.- 2020. -4-issue.-P.31-33.

8. Raimov G'. F. Methods of solving nonstandard problems in school physics.Namangan: NamSU Bulletin.-2020.-Issue 7.-P 300-303. 